\title{
Kandungan Radikal Bebas Sate Padang dan Sate Madura di sekitar kampus UIN Syarif Hidayatullah Jakarta
}

\author{
Sri Yadial Chalid \\ Program Studi Kimia FST UIN Syarif Hidayatullah Jakarta \\ Jalan Ir. H. Juanda No 95 Ciputat 15412 Indonesia \\ sriyadial@yahoo.com
}

\begin{abstract}
Abstrak
Telah dilakukan penelitian penentuan kadar radikal bebas pada makanan tradisional sate Padang dan Sate Madura yang diperdagangan di sekitar kampus UIN Syarif Hidayatullah Jakarta. Sate Madura yang diteliti adalah sate kambing yang dibumbui (SKB) dan sate kambing tanpa bumbu (SK) sedangkan sate Padang adalah sate daging yang sudah dibumbui (SP). Kadar radikal bebas yang terkandung pada sampel ditentukan secara spektrofotometri. Malondialdehid (MDA) sebagai pertanda terbentuknya radikal bebas membentuk kompleks yang berwarna merah jambu dengan Tiobarbituric acid (TBA). Warna merah jambu dari kompleks MDA-TBA diukur dengan spektrofotometer UV-Vis pada panjang gelombang $530 \mathrm{~nm}$. Kadar radikal bebas sate kambing Madura tanpa bumbu lebih tinggi dibandingkan dengan kadar radikal bebas sate kambing Madura pakai bumbu dan sate Padang. Secara umum disimpulkan bahwa baik sate Madura maupun sate Padang mengandung radikal bebas. Sate Padang mengandung radikal bebas paling rendah yaitu sebesar $0.000011 \pm 1.91 \times 10^{-6} \mathrm{M}$, kadar radikal bebas sate kambing Madura pakai bumbu adalah $0.000013 \pm 1.91 \times 10^{-6} \mathrm{M}$ dan $0.000051 \pm 6.57 \times 10^{-5} \mathrm{M}$ untuk sate Madura tanpa bumbu.
\end{abstract}

Kata Kunci: radikal bebas, Sate Padang, Sate Madura, MDA-TBA

\begin{abstract}
The determination of free radicals from traditional food of Padang Satay and Madura Satay had been done from surrounding area of Syarif Hidayatullah Islamic State University (UIN Jakarta). Madura satay have made of meat from goat with food additive (SKB) and without food additive (SK), while Padang satay made of meat of cow with the food additive. The concentration of free radicalon the sample was determined by spectrophotometry. Malondialdehide (MDA) is the indicated the formation of free radicals and reacted the complex compound with tiobarbituric acid (TBA) to form the reddish colors. The reddish colors from complex of MDA-TBA is measured by UV-Vis spectrophotometer on the wavelength of $530 \mathrm{~nm}$. The free radicals from Madura satay without food additive is higher than the Madura satay swith food additive and on the Padang satay. It could be generally conclude that Madura satay as well as Padang satay showed free radicals content. Padang satay containing free radicals lower $\left(0.000011 \pm 1.91 \times 10^{-6} \mathrm{M}\right)$ than on Madura satay with food additive $\left(0.000013 \pm 1.91 \times 10^{-6} \mathrm{M}\right)$ and without additive $\left(0.000051 \pm 6.57 \times 10^{-5} \mathrm{M}\right)$.
\end{abstract}

Keywords : free radical, Padang satay, Madura satay, MDA-TBA

\section{PENDAHULUAN}

Sate adalah makanan tradisional yang disukai oleh banyak orang dari semua lapisan umur, status sosial dan suku. Di Indonesia sendiri sate yang terkenal dan banyak digemari serta mudah ditemui adalah sate daging, sate kambing dan sate ayam. Sebagian masyarakat memahami bahwa mengkonsumsi sate kambing akan menambah vitalitas terutama vitalitas kaum pria, kebenaran asumsi ini memang harus dibuktikan secara klinis. Disamping sate adalah makanan yang enak, 
sedap dan mengenyangkan, sate tidak bebas seratus persen dari bahaya, terutama bahaya radikal bebas yang dihasilkan sebagai efek samping dari proses pengolahan daging menjadi sate.

Disamping daging baik daging sapi, ayam atau kambing kaya akan protein, makanan ini juga banyak mengandung lemak, mineral dan vitamin. Proses pengolahan dari bahan mentah menjadi makanan yang lezat dapat merusak kadar dan komposisi zat gizi yang terkandung pada bahan makanan tersebut. Vitamin, protein dan lemak adalah zat gizi yang mudah rusak ketika dipanaskan atau dibakar. Proses pembakaran daging menjadi sate biasanya oleh masyarakat kita dilakukan secara langsung di bawah bara api. Sate Padang dibuat dengan cara merebus daging terlebih dahulu dengan bumbu seperti kunyit, bawang putih, bawang merah, jahe dan lengkuas. Daging yang akan dijadikan sate direbus sampai empuk dan baru setelah itu dibakar di atas bara api. Proses perebusan dan pemberian bumbu ini dapat mengurangi kadar lemak pada daging dan bumbu yang digunakan merupakan bahan-bahan yang mengandung antioksidan yang dapat menangkal radikal bebas. Pada pedagang sate Madura proses pengolahan daging kambing menjadi sate kambing dilakukan tanpa proses perebusan. Pada penelitian ini dicoba melakukan dua jenis variasi perlakuan untuk sate kambing yaitu daging kambing dipotong-potong kecil dadu ditusuk dan langsung dibakar. Variasi kedua adalah daging kambing dipotong kecil dadu kemudian dibumbui dengan campuran bumbu, kunyit, bawang putih, bawang merah, jahe, lengkuas dan merica kemudian baru dibakar.

Teknik pembakaran dan pemanggangan seperti ini berpotensi menghasilkan molekul radikal bebas yang bersifat karsinogen seperti senyawa poli aromatic (HPA) dan Amin Heterosiklik. HPA merupakan kontaminan makanan yang berasal dari pengasapaan dan pembakaran batu bara. HPA yang pertama ditemukan terdiri dari lebih dari 100 komponen yang mengandung inti benzene dengan 3 sampai 7 cincin yang berkondensasi dan semua berasal dari reaksi radikal bebas melalui proses pirolisis dari gula, asam-asam amino dan lemak. HPA ini bersifat karsinogenik secara tidak langsung. Amin Heterosiklik merupakan karsinogen yang dihasilkan dari pembakaran atau pemanggangan yang berasal dari reaksi pirolisis asam amino triptopan, glutamate, lisin, ornitin dan fenilalanin (Sugimura et al. 1992)

Menurut beberapa hasil penelitian senyawa sampingan yang dihasilkan dari proses pembakaran makanan terutama makanan yang kaya lemak dan protein dapat membahayakan kesehatan. Penyakit kanker, diabetes, katarak, penuaan dini, artheroklerosis dan gagal ginjal merupakan akibat dari radikal bebas yang dikonsumsi dalam jumlah kecil dan sering. Efek sampingnya terhadap kesehatan muncul setelah tahunan dan bersifat terakumulasi. (Supari, 1996)

\section{Radikal Bebas}

Radikal bebas adalah molekul yang kehilangan satu elektron atau mempunyai elektron yang tidak berpasangan (Halliwell and Gutteridge 1999). Untuk memenuhi elektron yang hilang, radikal bebas mengambil satu elektron dari molekul lain sehingga molekul baru tersebut menjadi radikal bebas baru. Rangkaian reaksi ini berlangsung terus secara berantai sehingga berdampak negatif terhadap kesehatan (Halliwell B. 1994). Penyakit jantung koroner, diabetes, katarak, kanker dan katarak adalah contoh penyakit akibat radikal bebas (Supari 1996). Radikal bebas yang banyak ditemukan adalah : ${ }^{\circ} \mathrm{OH}$ (hidroksil), ${ }^{\circ} \mathrm{O}_{2}$ (Superoksida), $\mathrm{NO}^{\bullet}$ (nitrit oksida), LOO (lipid peroksida), $\mathrm{H}_{2} \mathrm{O}_{2}$ (hidrogen peroksida)

Radikal bebas berasal dari sumber endogen dan eksogen. Secara endogen radikal bebas pada organisme aerobik berasal dari: diperkirakan 1-5\% terjadi kebocoran elektron, elektron ini bereaksi dengan oksigen membentuk radikal superoksida, reduksi $\mathrm{O}_{2}$ menjadi superoksida pada fagositosis, pada peristiwa iskemi, reaksi Fenton dan HaberWeiss dan metabolisme eicosanoid. Secara eksogen radikal bebas berasal dari pencemaran lingkungan, asap kendaraan, bahan tambahan makanan dan rokok (Rice-Evan et al. 1991; Halliwell 1994).

Di dalam tubuh manusia sumber utama radikal bebas berasal dari makanan. Makanan olahan baik olahan rumahan ataupun pabrik berpotensi mengandung radikal bebas. Pengolahan makanan seperti membakar, memanggang, merebus tanpa ada kontrol suhu dan waktu dapat merusak makanan yang mengandung lemak dan protein. Makanan yang mengandung asam lemak tidak jenuh 
seperti asam oleat, linoleat dan linolenat mudah teroksidasi menjadi hidroperoksida (Donnely and Robinson, 1990)

\section{Efek Radikal Bebas Terhadap Kesehatan}

Pada tubuh manusia radikal bebas dapat merusak molekul-molekul seluler dan ekstraseluler seperti protein, asam lemak tidak jenuh ganda, glikoprotein dan bahan-bahan penyusun DNA seperti karbohidrat dan basa purin. Radikal bebas pada konsentrasi tinggi menyebabkan kematian sel, gangguan sistem enzim, merusak DNA dan RNA sehingga terjadi mutasi gen (Halliwell ang Gutteridge 1992; Oberley 2001). Sebagai akibat muncul berbagai penyakit degeneratif seperti: hipertensi, diabetes, iskemi reperfusi, inflamasi, kanker, parkinsons, alzheimer, arteroklerosis, penuaan dini dan down sydrome (Muhilal 1991; Halliwell and Gutteridge 1992)

\section{Analisa Kadar Radikal Bebas}

Reaksi tidak terkendali radikal bebas terhadap asam lemak dan komponen membran sel dapat menghasilkan malondialdehid (MDA), diena konyugasi dikarbonil dan asam 15-hidroperoksi-5,8,4,13 eikosatetraenoik (15HPETE). 1,1,3,3-tetraetoksipropan merupakam prekursor malondialdehid sehingga larutan standar dapat digunakan tetraetoksipropan.

Kadar MDA dapat dijadikan pertanda kerusakan oksidatif peroksida lipid atau lipoprotein yang kaya dengan asam lemak tidak jenuh jamak (PUFA). Penentuan kadar MDA juga dapat dilakukan dengan metoda HPLC (High Performance Liquid Chromatography), prinsip fluoresen dan pembentukan komplek berwarna antara MDA dengan TBA (Thiobarbituric acid). Metoda kompleks antara MDA dan TBA merupakan merupakan metode kuno tetapi sering digunakan karena praktis dan cukup sensitif (Buege and Aust, 1978). Warna komplek yang terbentuk terbentuk secara spektrofotometri pada panjang gelombang $535 \mathrm{~nm}$. Reaksi berlangsung dalam suasana asam pada $\mathrm{pH} 2-3$, tetapi kelebihan asam akan menghalangi pembentukan warna.

\section{METODE PENELITIAN}

\section{Alat}

Spektrofotometer sinar ultraviolet dan sinar tampak Perkin Elmer Lamda 25, Neraca analitik Explorer Pro EP214, Alat Destilasi, stop watch, pemanas listrik Thermolyne Cimarec 2, sentrifuge, tabung reaksi, vortex dan peralatan gelas.

\section{Bahan}

Sampel diambil dari pedagang sate seperti sate Padang, dan sate kambing Madura, Semua reagen yang digunakan mempunyai tingkat kemurnian yang tinggi keluaran Merck seperti Thiobarbituric Acid (TBA), Asam Klorida $\quad(\mathrm{HCl}), \quad$ larutan $\quad$ 1.1.3.3 tetraetoksipropan dan aquadest.

\section{Pengambilan Sampel}

Sebanyak $0,25 \mathrm{~kg}$ sample disampling, masing-masing sample diberi kode sebagai berikut: sate kambing tanpa bumbu (SK), sate kambing pakai bumbu (SKB), sate Padang (SP).

Sampel dibumbui sesuai dengan bumbu yang diracik tiap pedagang terdiri dari : kunyit, jahe, lengkuas, bawang merah, bawang putih, merica (lada) dan garam

\section{Ekstraksi Sample}

10 gram sample dihancurkan dalam waring blender untuk homogenisasi dengan campuran pelarut kloroform-metanol (2:1) selama beberapa menit. Homogenate yang diperoleh didiamkan beberapa menit, kemudian disaring dengan kertas saring bebas lemak. Filtrate dicuci dengan aquades sebanyak 0.2 kali volume filtrate, digojog dan didiamkan sampai dua bagian terpisah. Cairan bagian atas dibuang dengan menyedot hati-hati dengan pipet. Pencucian diulang $3 \mathrm{x}$ dengan aquades. Tambahkan sedikit methanol dan kloroform secukupnya (Sudarmadji 1997).

\section{Pengukuran Malondialdehid Sample}

Sebanyak $6 \mathrm{~mL}$ filtrat sampel SK, SKB. dan SP masing-masing dimasukkan ke dalam tabung reaksi, tambahkan 0,2 mL TBA 0,37\%. Larutan divorteks kemudian dipanaskan selama 15 menit dalam penangas air mendidih. Lalu diekstraksi dengan n- Heksana sebanyak $6 \mathrm{~mL}$ dan $\mathrm{H}_{2} \mathrm{O}$ sebanyak $6 \mathrm{~mL}$, akan 
terbentuk dua lapisan. Lapisan n-heksan dan lapisan kompleks TBA-MDA. Lapisan merah jambu kompleks TBA-MDA dipisahkan dan diukur besar serapannya dengan spektrofotometer UV-VIS pada panjang gelombang 530,7 nm (Rice-Evans, 1991).

\section{HASIL DAN PEMBAHASAN}

\section{Malondialdehid Standar dan Sampel}

Sebagai larutan standar untuk pengukuran radikal bebas digunakan 1,1,3,3tetraetoksipropan yang dihidrolisis dengan air. Senyawa 1,1,3,3-tetraetoksipropan bila dihidrolis dengan air menghasilkan malondialdehid. Data pengukuran absorban MDA standar dan sampel ditampilkan pada tabel 1 .

Tabel. 1. Data kadar MDA standar

\begin{tabular}{|c|l|l|}
\hline No & \multicolumn{1}{|c|}{$\begin{array}{c}\text { Konsentrasi } \\
(\mathbf{m M})\end{array}$} & \multicolumn{1}{|c|}{ Absorban } \\
\hline 1. & 0,00000 & 0,0000 \\
\hline 2. & 0,00002 & 0,1966 \\
\hline 3. & 0,00004 & 0,4157 \\
\hline 4. & 0,00008 & 0,7705 \\
\hline
\end{tabular}

Selanjutnya hasil analisa kadar malondialdehid sampel SK, SKB, dan SP disajikan pada tabel 2 .

Tabel 2. Kadar malondialdehid sampel

\begin{tabular}{|l|c|c|}
\hline No & Jenis Sampel & $\begin{array}{c}\text { Konsentrasi MDA } \\
(\mathbf{M})\end{array}$ \\
\hline 1 & SK & $0.000051 \pm 6.57 \times 10^{-5}$ \\
\hline 2 & SKB & $0.000013 \pm 1.91 \times 10^{-6}$ \\
\hline 3 & SP & $0.000011 \pm 1.91 \times 10^{-6}$ \\
\hline
\end{tabular}

SK : sate kambing tanpa bumbu, SKB : sate kambing pakai bumbu, SP : sate Padang.

Dari data kadar malondialdehid sampel sate kambing tanpa bumbu dan sate kambing pakai bumbu didapatkan bahwa kadar radikal bebas pada sate kambing bumbu lebih rendah dibandingkan dengan kadar radikal bebas sate kambing tanpa bumbu. Kecenderungan ini diperkirakan akibat dari pengaruh penggunaan bumbu. Bumbu yang ditambahkan pada sampel mengandung senyawa yang bersifat sebagai antioksidan.
Menurut Cakmak dan Marschner 1993 secara in-vitro dan in-vivo terbukti bahwa komponen bioaktif tanaman bersifat sebagai antioksidan yang dapat menangkal radikal bebas secara scavenger dan quencher.

Bumbu yang sering digunakan untuk keperluan masak seperti lada, jahe, lengkuas, kacang kedele, kacang tanah, bawang merah dan bawang putih mengandung senyawa bioaktif. Senyawa yang umumnya terdapat pada bumbu di atas adalah senyawa polifenol seperti tokoferol, flavanol, flavon, flavanol, antosianin (Halliwell and Gutteridge 1999). Vitamin $\mathrm{E}$, vitamin $\mathrm{C}$, klorofil, gingerol dan flavonoid dapat menangkal ROS (radical oxygen species) dan secara keseluruhan dapat menekan proses peroksidasi lipid (Cho et al 2000, Oberley L., 2001).

Secara umum bahwa semua sampel baik yang dibumbui atau tidak dibumbui mengandung radikal bebas. Hal ini dapat dijelaskan sebagai berikut bahwa kandungan protein dan lemak yang terdapat pada sampel terdegradasi menjadi pecahan radikal bebas. Dianatara ke tiga sampel, sate Padang mengandung radikal bebas sebesar $0.00011 \mathrm{M}$ dan paling rendah dibandingkan dengan sate kambing pakai bumbu ataupun tanpa bumbu. Proses perubusan pada suhu tertentu dapat mereduksi kadar lemak sehingga pada saat pembakaran jumlah lemak yang terdegradasi menjadi radikal bebas juga menurun, apalagi penambahan bumbu yang megandung antioksidan dapat mereduksi radikal bebas dalam jumlah yang signifikan. Walaupun sudah diyakini bahwa radikal bebas mempunyai andil dan menurunkan kualitas kesehatan dan menyebabkan penyakit tertentu tetapi sejauh ini Pemerintah (Depkes) belum menetapkan ambang batas jumlah radikal bebas yang dapat dikonsumsi dan ditoleransi oleh tubuh.

\section{KESIMPULAN}

Makanan yang dibakar seperti sate baik sate daging, Sate Padang ataupun Sate Madura umumnya mengandung radikal bebas walaupun dengan konsentrasi yang relatif rendah. Makanan yang dibumbui terlebih dahulu sebelum dibakar mengandung kadar radikal bebas lebih rendah daripada makanan bakar tanpa bumbu sehingga disimpulkan 
bahwa bumbu yang terdiri dari bawang merah, bawang putih, jahe, lengkuas dan kunyit dapat menurunkan kadar radikal bebas.

Dari makanan bakar yang diuji didapatkan bahwa daging kambing bakar tanpa dibumbui terlebih dahulu mengandung radikal bebas paling tinggi dan sate Padang mengandung radikal bebas paling rendah

\section{Saran}

Penurunan kadar radikal bebas pada makanan bakar yang dibumbui diperkirakan akibat dari kandungan komponen bioaktif dari bumbu yang digunakan dan komponen bioaktif tersebut bersifat sebagai antioksidan, untuk membuktikan hal ini perlu dilakukan penelitian tentang komponen bioaktif apa yang berperan menangkal radikal bebas.

\section{DAFTAR PUSTAKA}

1. Buege and Aust. 1978. Methods for TBAReaction. dalam Rice-Even Diplock and Symons, editor. Technique in Free Radical Research. Amsterdam. Tokyo Elsivier. Hlm 147-148

2. Cakmak I and Marschner H. 1993. Effect Zink Nutritional Status on Activities of Superoxide Radical and Hydrogen Peroxide Scavenging Enzymes in Bean Leaves. Journal Plant and Soil. Vol. 155. No. 156. Hlm 127-130

3. Cho KJ, et al. 2000. Effect of Bioflavonoid Extracted from the Bark of Pinus Maritima on Proinflammator Cytokine Interleukin-1 Productionin Lipopolysaccharide Stimulated $R A W$ 267.7. Journal Toxicology and Applied Pharmacology. Vol. 168. Hlm.64-71

4. Donnely JK and Robinson DS. 1990 Oxygen Radicals in Living System and in Food. BNF Nutri Bull, vol. 15. Hlm 115-129

5. Halliwell B and Gutteridge JMG. 1999. Free Radical in Biology and Medicine. Oxford University Press. Ed. 3. Hlm 105 -220

6. Halliwell B. 1994. Free Radical, Antioxidant and Human Disease : Curiosity, Cause or Consequence. The Lancet 344: hlm 721-724

7. Muhilal. 1991. Teori Radikal Radikal Bebas dalam Gizi dan Kedokteran. Cermin Dunia Kedokteran No. 73. Pusat Penelitian dan Pengembangan Gizi, Departemen Kesehatan RI : Bogor
8. Oberley L. 2001. Free Radicals Biology; A Moleculer Approach Suppressing Cancer Cell Growth. UI Healty Care. Vol. 2. No.3

9. Rice-Evans CA, Diplock AT, Symons MCR. 1991. Technique in Free Radical Research. Elsivier Amsterdam, London, Tokyo

10. Sudarmadji Selamet, Bambang Haryono Suhadi. 1997. Prosedur Analisa untuk Bahan Makanan dan Pertanian Edisi IV. Liberty, Yogyakarta

11. Supari F. 1996. Radikal Bebas dan Patofisiologi Beberapa Penyakit. Di dalam Senyawa Radikal dan Sistem Pangan: Reaksi Biomolekuler, Dampak Terhadap Kesehatan dan Penangkalan. Prosiding Seminar, Pusat Studi Pangan dan Gizi-IPB dan Kedutaan Besar Perancis. Jakarta, Bogor

12. Sugimura T. Wakabayashi K, Nagao M, Ohgaki H. 1992. Heterocyclic Amines in Cooked Food. dalam Food Toxicology A Perspective on the Relative Risks.Taylor SL, Scanlan $R A$. Marcel Dekker D 